Bangladesh J. Bot. 48(4): 1143-1151, 2019 (December)

\title{
GENOTYPE-ENVIRONMENT INTERACTION ON STABILITY OF GRAIN YIELD AND PHYSIO-BIOCHEMICAL TRAITS IN BREAD WHEAT (TRITICUM AESTIVUM L.)
}

\author{
ViJay Sharma*, RB Dubey ${ }^{1}$ and Rumana Khan ${ }^{1}$ \\ Department of Genetics and Plant Breeding, Banda University of Agriculture \\ and Technology, Banda- 210001, India
}

Keywords: Bread wheat, Terminal heat tolerance, Grain yield, Physiological traits, Protein content, Stability analysis

\begin{abstract}
To assess the stability of genotypes for grain yield and physio-biochemical traits associated with terminal heat tolerance pooled analysis of 8 genotypes of wheat of diverse origin, their $28 \mathrm{~F}_{1}$ progeny and 2 checks were carried out in 4 different environments i.e. early sown $\left(\mathrm{E}_{1}\right)$, normal sown $\left(\mathrm{E}_{2}\right)$, late sown $\left(\mathrm{E}_{3}\right)$ and very late sown $\left(\mathrm{E}_{4}\right)$ conditions. The pooled analysis of variance due to environment (for proline and chlorophyll content), genotypes and genotype $\times$ environment interaction was significant for all the traits under consideration. This indicated the distinct and differential effect of the different sowing conditions (environment) and differential response of all the genotypes chosen for the study. The five stable wheat hybrids viz., HI $1544 \times$ HD 2987, Raj 4037 × HD 2987, PBW $175 \times$ HD 2987, HD $2932 \times$ Raj 4079 and PBW $175 \times$ Lok 1 showed higher mean values, favourable regression coefficient and deviation from regression coefficient for grain yield and other associated characters, thus emerged as stable genotypes as per criteria of stability analysis. Similarly, some genotypes showed specific adaptations for poor or heat stress environment.
\end{abstract}

\section{Introduction}

Wheat (Triticuma estivum L.) $(2 \mathrm{n}=6 \mathrm{x}=42)$, a self-pollinated crop of the Poaceae is the world's largest cereal crop (Sharma et al. 2019). It is the staple food for over 27 per cent of global population in more than 40 countries. It is popularly known as 'Stuff of life or King of the cereals' because of the acreage occupied, high productivity and the prominent position it holds in the international food grain trade. The main wheat growing countries include Australia, Canada, China, France, India, Russia, Turkey, Ukrain and USA. It is the second most important grain crop after rice in India and has tremendous yield potential. In India, area and production of wheat during year 2014 - 2015 was recorded 30.97 million ha and 88.94 million tonnes with an average productivity of $2872 \mathrm{~kg} / \mathrm{ha}$ (DAC\&FW 2015). Wheat grain contains starch $(60-68 \%)$, protein $(6-$ $21 \%)$, fat $(1.5-2.0 \%)$, cellulose $(2.0-2.5 \%)$, minerals $(1.8 \%)$ and vitamins. The uniqueness of wheat in contrast to other cereals is that wheat contains gluten protein which enables leavened dough to rise by forming minute gas cells and this property enables bakers to produce light breads.

Wheat is a thermo-sensitive crop mostly grown in temperate environment, but on account of its genetic diversity, it has extended its frontiers and has become adapted to nearly all the climates of the world. In subtropical regions it is cultivated in winter season but it exposed to high temperature $\left(>35^{\circ} \mathrm{C}\right)$ stress at the end of the season i.e. during grain filling. Rise in temperature at the time of grain filling is referred to as terminal heat stress which reduces yield and decreases quality of wheat in many wheat environments around the world (Reynolds et al. 2001, Hays et al. 2007). The phenotypic performance of a genotype is not necessarily the same under diverse agroecological conditions (Ali et al. 2003).

*Author for correspondence: <107vijaysharma@gmail.com>. ${ }^{1}$ Department of Plant Breeding and Genetics, Maharana Pratap University of Agriculture and Technology, Udaipur-313001, India. 
Breeding genotypes for heat tolerance has become an integral component of wheat improvement. To achieve this goal, growing of breeding lines over time and space has become an integral part of any plant breeding programme. The task of breeder is to screen out genotypes planted at different interval and to those genotypes which are suitable for wider range of planting. Information on phenotypic stability is useful for the selection of crop varieties as well as for breeding programs. Some genotypes may perform well in certain environment, but, fail in several others. Genotype-environment interaction is extremely important in the development and evolution of plant varieties because they reduce the genotypic-stability values under diverse environments (Herbert et al. 1995). Progress from selection is also reduced due to a large effect of genotypes and environment interaction as shown by Comstock and Moll (1963). Hence a study of $\mathrm{G} \times \mathrm{E}$ interaction can lead to successful evolution of wheat cultivars for stability in yield performance in different environments.

In the present study, the approach suggested by Eberhart and Russell (1966) has been employed to understand the differential $\mathrm{G} \times \mathrm{E}$ interaction of parents and their hybrids to access the stability of individual genotypes. An understanding of environmental and genotypic causes leading to $\mathrm{G} \times \mathrm{E}$ interactions are important at all stages of plant breeding including ideotype design, parental selection, selection based on traits and selection based on yield (Jackson et al. 1996, Yan and Hunt 1998). This understanding can be used to establish breeding objectives, identify ideal test conditions and formulate recommendations for areas of optimal cultivar adaptation. Thus, this study was undertaken to evaluate wheat genotypes for their yield stability under diverse temperature regimes.

\section{Materials and Methods}

Eight diverse wheat genotypes (Table 1) selected on the basis of broad range of genetic diversity for major yield components, geographical origin, heat tolerance and their suitability for different yield traits, were crossed in half diallel fashion resulting in $28 \mathrm{~F}_{1} \mathrm{~s}$ at Research Farm, Rajasthan College of Agriculture, Udaipur (Rajasthan) during the year 2014-15. These eight parents and their $28 \mathrm{~F}_{1} \mathrm{~s}$ were grown in a randomized block design with three replications under early $\left(E_{1}\right)$, normal $\left(E_{2}\right)$, late $\left(E_{3}\right)$ and very late $\left(E_{4}\right)$ sown conditions. The environments were created by four different date of sowings (Table 2). Row-to-row and plant-to-plant distances were 30 and $10 \mathrm{~cm}$, respectively in each environment. Recommended plant protection procedures were followed for raising the crop in all the environments.

Table 1. Particulars of wheat parent material used.

\begin{tabular}{lll}
\hline Sl. No. & Name of cultivar & Pedigree \\
\hline 1. & HD 2932(PUSA WHEAT 111) & KAUZ/STAR//HD 2643 \\
2. & GW 366 & DL 802-3/GW 232 \\
3. & Raj 4037 & DL 788-2 / RAJ 3717 \\
4. & PBW 175 & HD 2160 /WG 1025 \\
5. & HI 1544 (PURNA) & HINDI 62/BOBWHITE/ CPAN 2099 \\
6. & Raj 4079 & UP 2363/WH 595 \\
7. & HD 2987(PUSA BAHAR) & HI101 1/HD2348//MENDOS//IWP 72/DL 153-2 \\
8. & LOK 1 & S-308 / S 331, \\
\hline
\end{tabular}


Table 2. The details of the four environments.

\begin{tabular}{ll}
\hline Environment & Date of sowing \\
\hline $\mathrm{E}_{1}$ (Early sown) & October 27, 2015 \\
$\mathrm{E}_{2}$ (Normal sown) & November 17, 2015 \\
$\mathrm{E}_{3}$ (Late sown) & December 07,2015 \\
$\mathrm{E}_{4}$ (Very late sown) & December 27, 2015 \\
\hline
\end{tabular}

The observations were recorded on randomly selected competitive plants from each plot in each replication in case of parents, $F_{1}$ progeny and checks in all the four environments separately on seven distinct characters. The data on grain yield per plant, leaf canopy temperature, proline content, chlorophyll content, chlorophyll stability index, heat injury and total protein content were recorded for statistical analysis.

A combined analysis of variance was undertaken across the test environments. The phenotypic stability of genotype for different characters was estimated according to model proposed by Eberhart and Russell (1966).

The statistical model of the analysis was as follows:

where,

$$
\mathrm{Y}_{\mathrm{ij}}=\mu_{\mathrm{i}}+\beta_{\mathrm{i}} \mathrm{I}_{\mathrm{j}}+\delta_{\mathrm{ij}}
$$

$\mathrm{Y}_{\mathrm{ij}}=$ Mean performance of $\mathrm{i}^{\text {th }}$ genotype in $\mathrm{j}^{\text {th }}$ environment

$\mu_{i}=$ Mean of $i^{\text {th }}$ genotype over all the environments

$\beta_{\mathrm{i}}=$ The regression coefficient of $\mathrm{i}^{\text {th }}$ genotype

$\delta_{\mathrm{ij}}=$ Deviation from regression of the $\mathrm{i}^{\text {th }}$ genotype

$I_{j}=$ The environmental index for $j^{\text {th }}$ environment

Two parameters of stability viz. regression coefficient $\left(\mathrm{b}_{\mathrm{i}}\right)$ and mean square deviation from linear regression $\left(S^{2} d_{i}\right)$ were estimated as follows (Sing and Chaudhary 1979).

$$
b_{i}=\frac{\sum_{j=1}^{l} Y_{i j} \times I_{j}}{\sum_{j=1}^{l} I_{j}^{2}}
$$

The mean squares deviation from regression $\left(\mathrm{S}^{2} \mathrm{~d}_{\mathrm{i}}\right)$ was estimated as:

$$
S_{d i}^{2}=\left(\frac{\sum_{j=1}^{l} \hat{\delta}_{i j}^{2}}{l-2}\right)-\frac{S_{e}^{2}}{r}
$$

where, $\mathrm{S}_{\mathrm{e}}^{2}=$ Estimate of pooled error mean square and

$$
\sum_{j}^{l} \hat{\delta}_{i j}^{2}=\left(\sum_{j=1}^{i} Y_{i j}^{2}-\frac{Y_{i}^{2}}{l}\right)-\frac{\left(\sum_{j=1}^{i} Y_{i j}^{2} \cdot I_{j}\right)^{2}}{\sum_{j=1}^{i} I_{j}^{2}}
$$


The linear regression coefficient $\left(b_{i}\right)$ of the relationship between yield for genotype at each location and the yield for mean location is the measure of the linear responses to environmental change. The mean square for deviation from the regression $\left(S^{2} d_{i}\right)$ measures the consistency of this response: in other words, it is a measure of heterogeneity.

\section{Results and Discussion}

The analysis of variance representing the mean squares due to different sources of variation for different characters is presented in Table 3. The variance due to environment was significant for proline and chlorophyll content indicating the distinct and differential effect of the different sowing conditions. The pooled analysis of variance for stability revealed that genotypes were found to be highly significant for all the characters when tested against pooled error as well as pooled deviation indicating thereby differential response of all the genotypes selected for the study. The variance due to $G \times E(L)$ have shown significant interaction for all the characters showing differential response to the genotypes to the all these environmental conditions. Highly significant $\mathrm{G} \times \mathrm{E}$ interactions for many wheat traits were previously reported by Hamam and Khaled (2009) and Tripura et al. (2011).

Significant mean squares due to $\mathrm{E}+(\mathrm{G} \times \mathrm{E})$ for all the characters revealed that the genotypes interacted considerably with environmental conditions that existed under different conditions of sowing. The significant variances due to pooled deviation components to the proline content, chlorophyll content and heat injury suggested that the genotypes differed significantly with respect to their stability for this characters. Similar results for one or more characters in wheat were also reported by Arya et al. (2004), Amin et al. (2005), Meena et al. (2014).

Table 3. Analysis of variance over the environment (Eberhart and Russell 1966).

\begin{tabular}{|c|c|c|c|c|c|c|c|}
\hline \multirow{2}{*}{$\begin{array}{l}\text { Sl. } \\
\text { No. }\end{array}$} & \multirow[t]{2}{*}{ Characters } & \multicolumn{2}{|c|}{ Genotype $\mathrm{E}+(\mathrm{G} \times \mathrm{E})$} & \multirow{2}{*}{$\begin{array}{l}\text { E (L) } \\
{[1]}\end{array}$} & \multirow{2}{*}{$\begin{array}{l}\mathrm{G} \times \mathrm{E}(\mathrm{L}) \\
{[37]}\end{array}$} & \multirow{2}{*}{$\frac{\text { Pool dev. }}{[76]}$} & \multirow{2}{*}{$\begin{array}{l}\text { Pool error } \\
{[296]}\end{array}$} \\
\hline & & [37] & {$[114]$} & & & & \\
\hline 1. & Grain yield/plant $(\mathrm{g})$ & $18.13 * *$ & $11.19 * *$ & 0.82 & $33.78 * *$ & 0.33 & 0.54 \\
\hline 2. & Leaf canopy temp. $\left({ }^{0} \mathrm{C}\right)$ & $1.43 * *$ & $7.86^{* *}$ & 0.61 & $23.94 * *$ & 0.12 & 0.17 \\
\hline 3. & Proline content $(\mu \mathrm{g})$ & $34.10^{* *}$ & $63.43 * *$ & $4.86^{* * *}$ & $192.92 * *$ & $1.16^{* *}$ & 0.16 \\
\hline 4. & Chlorophyll content (mg/g) & $0.42 * *$ & $0.05 * *$ & $0.004 *$ & $0.15^{* *}$ & $0.002 * *$ & 0.00 \\
\hline 5. & Chlorophyll stability index & $31.02 * *$ & $5.03 * *$ & 0.34 & $15.03 * *$ & 0.22 & 0.19 \\
\hline 6. & Heat injury (\%) & $110.87 * *$ & $20.19 * *$ & 1.45 & $59.60 * *$ & $1.24 * *$ & 0.72 \\
\hline 7. & Total protein content (\%) & $1.20 * *$ & $0.11 * *$ & 0.008 & $0.32 * *$ & 0.01 & 0.02 \\
\hline
\end{tabular}

*, ** Significant at 5 and 1 per cent level, respectively. Degree of freedom indicated within third bracket [ ].

The estimates of stability parameters like mean performance of the genotypes, regression coefficient $\left(\mathrm{b}_{\mathrm{i}}\right)$ and deviation from the regression $\left(\mathrm{S}^{2} \mathrm{~d}_{\mathrm{i}}\right)$ for seven different characters are presented in Table 4. In the present study, linear regression is regarded as measure of responsiveness and deviation from regression as measure of stability of a particular genotype. The genotypes with higher per se performance with non-significant $S^{2} d_{i}$ were classified on the basis of regression coefficient $\left(b_{\mathrm{i}}\right)$. The genotypes with $b_{\mathrm{i}}<1$ (significantly less than 1 ) were identified for adverse environmental conditions, $b_{i}>1$ (significantly higher than 1) for favourable environmental conditions and $b_{i}=1$ for unknown or unpredictable environmental conditions. A genotype is considered to be stable in performance if it has high mean performance, unit regression coefficient $\left(b_{i}=1\right)$ and least deviation from regression $\left(S^{2} d_{i}=0\right)$. 


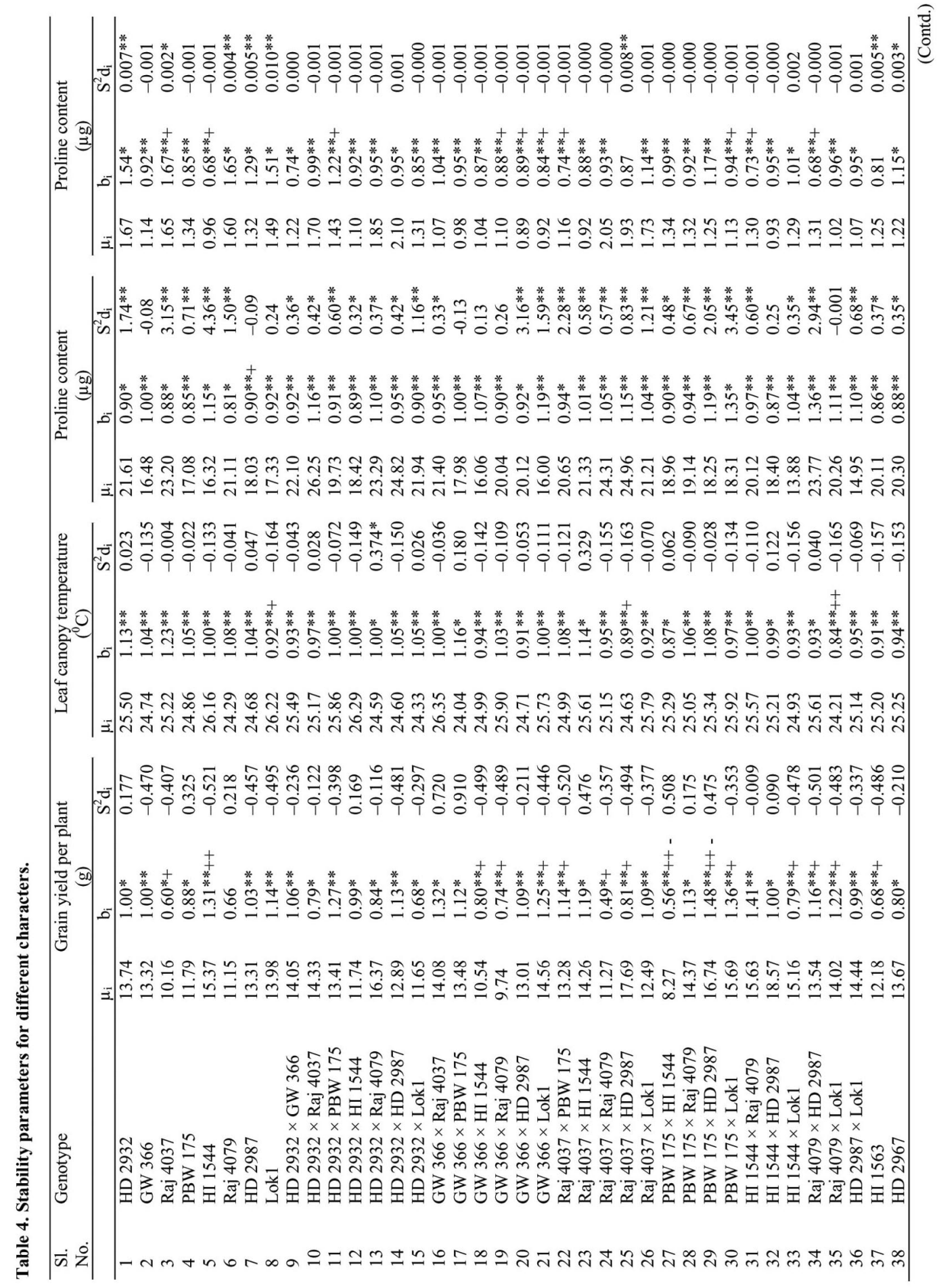




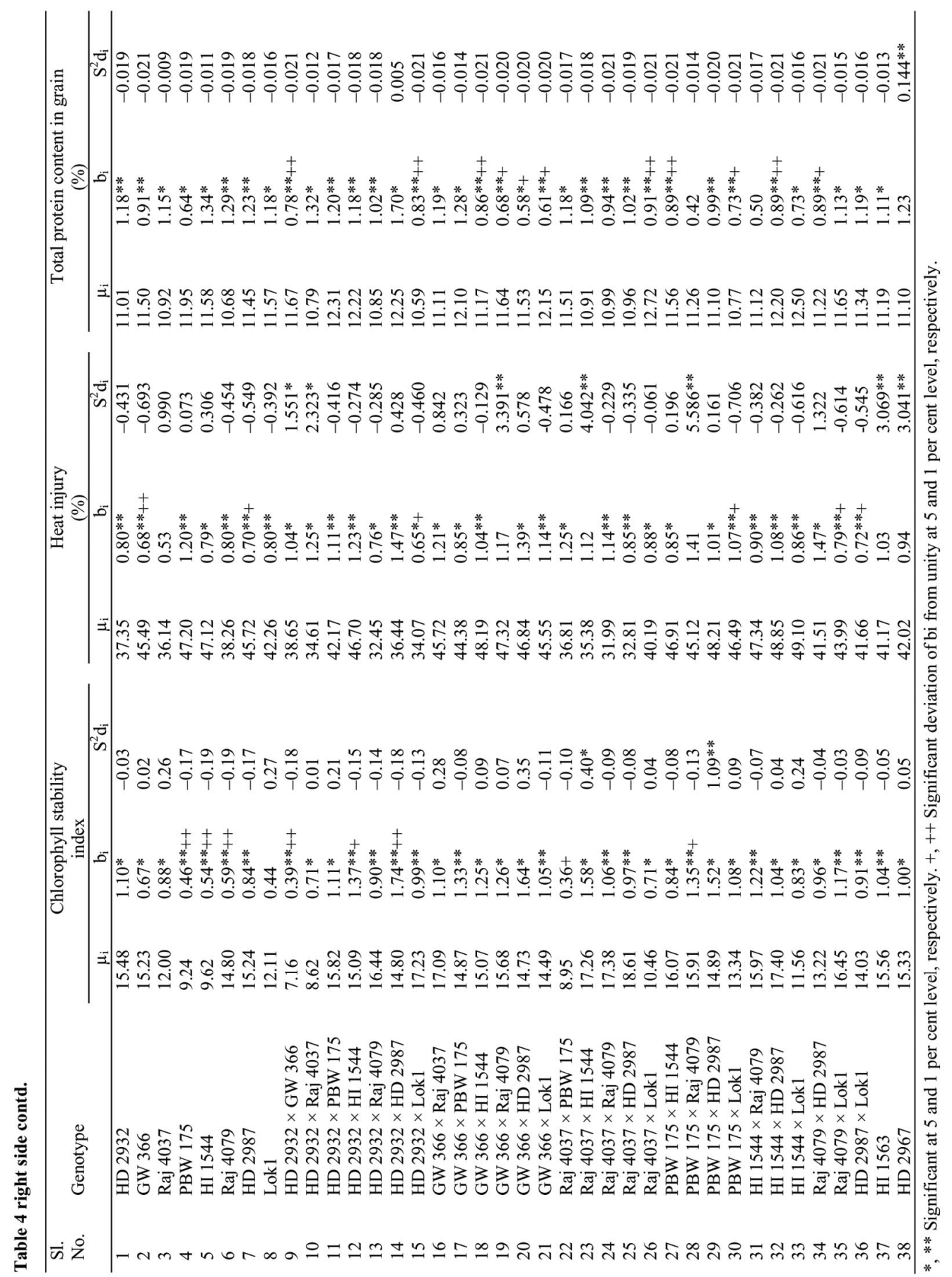


For grain yield per plant, all the parents and hybrids depicted non-significant deviation from regression $\left(\mathrm{S}^{2} \mathrm{~d}_{\mathrm{i}}\right)$, were stable and predictable for this trait. Out of these eight parents, parent HD 2932 and HD 2987 had regression coefficient around unity $\left(b_{i}=1\right)$ with high mean value than population mean, indicated its suitability and stability of performance under varied environments. Parents HI 1544 and Lok 1 showed regression coefficient greater than unity $\left(b_{i}>1\right)$ with high average value than population mean indicating its stability under favorable environments. Among hybrids, hybrid HD 2932 × Raj 4037, HD 2932 × Raj 4079, Raj 4037 × HD 2987 and HI $1544 \times$ Lok 1 exhibited regression coefficient less than unity $\left(b_{i}<1\right)$ with high mean value than population mean, indicating its stability under unfavorable environments. Hybrids HD $2932 \times \mathrm{GW}$ 366, HI $1544 \times$ HD 2987 and HD $2987 \times$ Lok 1 exhibited regression coefficient around unity $(\mathrm{bi}=1)$ with high mean value than population mean, indicating its suitability and stability of performance under different environments. Hybrids GW $366 \times$ Raj 4037, GW $366 \times$ Lok 1, Raj $4037 \times$ HI 1544, PBW $175 \times$ Raj 4079, PBW $175 \times$ HD 2987, HI $1544 \times$ Raj 4079, Raj $4079 \times$ HD 2987 and Raj $4079 \times$ Lok 1 had regression coefficient greater than unity $\left(b_{i}>1\right)$ with high mean value than population mean, indicating its suitability and stability under favorable environments.

Parents HD 2932, HI 1544, HD 2987 and Lok 1 also showed stable performance for leaf canopy temperature. In addition to this characters, parent HD 2932 also exhibited stable performance for heat injury, while for chlorophyll stability index parents HD 2987 and Lok 1; for total protein content parents HI 1544 and Lok 1, showed stable performance. For proline content and chlorophyll content none of genotypes showed the stable performance.

Comparative study of five stable hybrids viz., HI $1544 \times$ HD 2987, Raj $4037 \times$ HD 2987, PBW $175 \times$ HD 2987, HD $2932 \times$ Raj 4079 and PBW $175 \times$ Lok 1 resulted showed that the hybrids were stable for grain yield per plant and also depict stability in respect of its one or more physio-biochemical traits like leaf canopy temperature, proline content, chlorophyll content, chlorophyll stability index, heat injury and total protein content (Table 5). The results indicate that the stability of various traits might be responsible for the observed stability of different hybrids for grain yield per plant. Sixteen hybrids had above average mean value for grain yield per plant and non-significant deviation from regression $\left(\mathrm{S}^{2} \mathrm{~d}_{\mathrm{i}}\right)$ with high, low or unit regression values therefore, categorized as stable, better for good environment and poor environment. The stability of genotypes revealed that none of the parents and hybrids were ideal for better as well as poor environment for all the characters. The chances for selection of stable hybrids could be strengthened by selection in favour of stability in individual environment. Similar trends for adaptability of genotypes were also observed by Gowda et al. (2010), Ameen (2012), Meena et al. (2014) and Mohtasham et al. (2014).

Table 5. Stable hybrids identified on the basis of high mean for grain yield per plant along with stability of component traits.

\begin{tabular}{llll}
\hline $\begin{array}{l}\text { Sl. } \\
\text { No. }\end{array}$ & Hybrids & $\begin{array}{l}\text { Grain yield/plant } \\
(\mathrm{g})\end{array}$ & $\begin{array}{l}\text { Stable for component } \\
\text { traits }\end{array}$ \\
\hline 1. & HI 1544 $\times$ HD 2987 & 18.57 & $\mathrm{TP}^{++}$ \\
2. & Raj 4037 $\times$ HD 2987 & 17.69 & $\mathrm{LCT}^{++}, \mathrm{H}^{++}$ \\
3. & PBW 175 $\times$ HD 2987 & 16.74 & $\mathrm{GY}^{+}$ \\
4. & HD 2932 $\times$ Raj 4079 & 16.37 & $\mathrm{GY}^{++}, \mathrm{CSI}^{++}, \mathrm{H}^{++}$ \\
5. & PBW 175 $\times$ Lok 1 & 15.69 & - \\
\hline
\end{tabular}

,+++ Better for favourable and unfavourable environment. GY: Grain yield/plant. H: Heat injury. TP: Total protein content. LCT: Leaf canopy temperature. CSI: Chlorophyll stability index. 
According to Eberhart and Russell (1966), a genotype having high mean performance with $b_{i}$ equal to unity and $S^{2} d_{i}$ equal to zero will be well adapted to all the environments. Accordingly, the above mentioned genotypes, which showed desirable performance not only for grain yield but also for associated characters, emerged as potential genotypes. These genotypes could be used to develop new genotypes with combination of stable characters. Similar findings were also reported by Madariya et al. (2001) and Tripura et al. (2011).

\section{Acknowledgements}

The first author (VS) expresses thanks the Department of Science and Technology, Government of India for providing Inspire Fellowship for Ph.D. research work and to Dr. Jagdish Choudhary, Department of Agronomy, Rajasthan College of Agriculture, Udaipur for providing seed materials, untiring help and assistance during the field experiments.

\section{References}

Ali N, Javidfar F and Mirza Y 2003. Selection of stable rapeseed (Brassica napus L.) genotypes through regression analysis. Pak. J. Bot. 35: 175-183.

Ameen TE 2012. Stability analysis of selected wheat genotypes under different environment conditions in Upper Egypt. African J. Agri. Res.7(34): 4838-4844.

Amin M, Mohammad T, Khan AJ, Irfaq M, Ali A and Tahir GR 2005. Yield stability of spring wheat (Triticum aestivum L.) in the northwest frontier province, Pakistan. Songklanakarin J. Sci. Technol. 27: 1147-1150.

Arya VD, Pawar IS and Lamba R 2004. Phenotypic stability for yield, its components and quality traits in bread wheat. Nat. J. Plant Improv. 6: 9-13.

Comstock RE and Moll RH 1963. Genotype $\times$ environmental interaction. In: Statistical Genetics and Plant Breeding (Ed. W.D. Hanson and H.F. Robinson). NAS-NRC pub. 1982. pp. 164-196.

DAC\&FW 2015. Directorate of economics and statics, Department of Agriculture Cooperation and Farmers Welfare.

Eberhart SA and Russell WA 1966. Stability parameters for comparing varieties. Crop Sci. 6: 36-40.

Gowda DSS, Singh GP, Singh AM, Deveshwar JJ and Ahlawat A 2010. Stability analysis for physiological and quality parameters in wheat (Triticum aestivum). Indian J. Agric. Sci. 80(12): 1028-1032.

Hamam KA and Khaled GA 2009. Stability of wheat genotypes under different environmnts and their evaluation under sowing dates and nitrogen fertilizer levels. Aus. J. Basic and App. Sci. 3(1): 206-217.

Hays D, Mason JH, Do Menz M and Reynolds M 2007. Expression quantitative traits loci mapping heat tolerance during reproductive development in wheat (Triticum aestivum) In: Wheat production in stressed environments (eds Buck HT, Nishi JE and Salmon N) Springer. Netherlands: 373-382.

Hebert Y, Plomion C and Harzic N 1995. Genotypic $\times$ environment interaction for root traits in maize as analysed with factorial regression models. Euphytica 81: 85-92.

Jackson P, Robertson M, Cooper M and Hammer G 1996. The role of physiological understanding in plant breeding, from breeding perspective. Field Crop Res. 49:11-37.

Madariya RB, Poshiya VK and Kavani RH 2001. Phenotypic stability of yield and its contributing characters in bread wheat (T. aestivum). Madras Agric. J. 88(10-12): 648-650.

Meena HS, Kumar D, Srivastava TK and Prasad SR 2014. Stability for grain yield and its contributing traits in bread wheat (Triticumaestivum). Indian J. Agric. Sci. 84(12): 1486-1495.

Mohtasham M, Peyman S and Rahmatollah K 2014. Stability analysis of durum wheat genotypes by regression parameters in dryland conditions. Acta Universitatis Agriculturae et Silviculturae Mendelianae Brunensis 62(5): 1049-1056. 
Reynold MP, Ortiz-Monasterio JI and McNab A 2001. Application of physiology in wheat breeding. CIMMYT, El Batan, Mexico. http://www.cimmyt.org/research/wheat/map/research_results/wphysio/ WPhysio_contents.pdf

Sharma V, Dodiya NS, Dubey RB and Khan R 2019. Combining ability analysis in bread wheat (Triticum aestivum L.) under different environmental conditions. Bangladesh J. Bot. 48: 85-93.

Sing RK and Chaudhary BD 1979. Biometrical methods in quantitative genetic analysis. Kalayni Publishers, New Delhi, pp. 304.

Tripura K, Singh GP, Singh AM, Arora A, Ahlawat A and Sharma RK 2011. Stability analysis for physiological parameters and grain yield in bread wheat (Triticum aestivum L.). Indian J. Plant Physiol. 16: $26-34$.

Yan W and Hunt LA 1998. Genotype by environment interaction and crop yield. Pl. Breed. Reviews 16: 135-179.

(Manuscript received on 13 May, 2018; revised on 5 February, 2019) 